\title{
Stuck in the middle
}

\section{日本の株式市場で足をすくわれた 外資系バイオテク企業}

Nature Vol.442(237)/20 July 2006

日本の株式市場に外資系バイオテク企業として初めて上場した会社が、制度的な問題で身動きがとれなくなって いる。しかし、この経験は他の企業の教訓になるであろう。冬野いち子が報告する。

日本を資金調達の拠点に選ぶ外資系企 業は少ない。ルール、規制、法律、文 化の相違のために極めて面倒なことに なるからだ。ところが昨年初め、日本 人の医学博士 2 人によって米国カリ フォルニア州サンディエゴに設立され たバイオテク会社「メディシノバ」は、 古い型を打ち破ろうと立ち上がった。

メディシノバ社にとって滑り出し は上々だった。世界のライバル企業 が新規企業の立ち上げに苦戦してい た 2005 年 2 月に新規株式公開を行 い、1 億 1000 万ドル（約 120 億円） を調達した。複数の薬物候補が開発 段階にあり、日本の製薬会社から薬 物候補を導入し、日本よりはるかに 収益性の高い米国市場で臨床開発. 販売するという新しいビジネスモデ ルをもつ同社は、大きく羽ばたくと 思われていた。

ところが期待は長く続かなかった。 新興企業向け株式市場のヘラクレス （大阪）に上場した直後からメディシ ノバ社の株価は下落し始め(グラフ 参照)、現在の株価は発行価額だった
400 円（3 ドル 44 セント）の約 3 分の 1 となっている。

株価低迷の理由の 1 つは、日本国 内のバイオテクノロジー部門の全般 的な沈滞とされる。これに対しては、 政府による規制緩和の公約にもかか わらず、日本の株式市場が外資系企 業を受け入れることのむずかしさが ここに表れているというのが、ファ ンドマネージャーやアナリストの見 方だ。「メディシノバ社のチャレンジ ングな姿には感心しました。でも制 度的な問題がいくつかあったという ことが、後からわかったのです。」こ う語るのは、日本最大のベンチャー

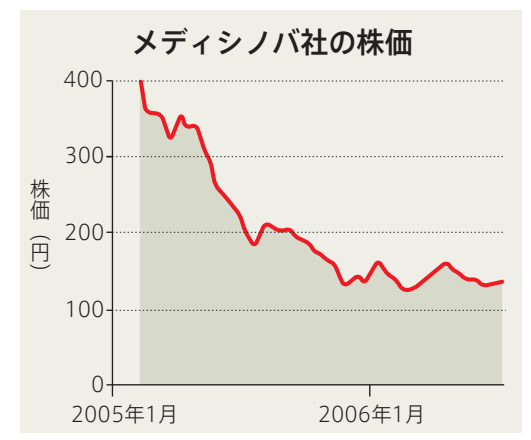

キャピタル会社ジャフコの縣（あが た）久二常務取締役である。

メディシノバ社は、田辺製薬 (本 社：大阪）から分離独立して 2000 年に設立された。田辺製薬は、循環 器系を専門とする中堅製薬会社であ る。メディシノバ社の初代社長は再 建外科医の清泉貴志だったが、2005 年に退職し、現在は岩城裕一が最高 経営責任者となっている。

メディシノバ社は、証券会社や報 道機関を含めて日本の証券業界の一 部から差別を受けてきた、と岩城は 主張する。外資系会社の株式取引に 関する規則によって、投資家が外資 系会社の株式を保有しにくくなって いる、と彼はいう。また、日本の投 資家が利用する情報資源の多くには 外資系企業に関するデータがなく、 その結果、一部の投資家のポートフォ リオから外資系企業が締め出しを食 らっている、とも岩城は主張する。

「弊社にとって市場との対話が制限さ れているのは悲しいことです。日本の証 券市場のグローバル化への先鞭になれ 
たらいいと思っているのですが、あまり にも犠牲も多いのです」と岩城は話す。

メディシノバ社のビジネスモデルは、 薬物候補のライセンスを主に日本国内 の企業から取得し、米国とヨーロッパ で臨床試験を終了させることである。

日本国内の製薬会社が海外で臨床試 験を実施するのは、手続きの複雑さや 臨床治験を代行する現地会社を使い己 なすのがむずかしいため、どこも非常 に苦労している。そのため、メディシ ノバ社のビジネスモデルは魅力的であ る。南カリフォルニア大学（米国ロサ ンゼルス）にも所属している岩城は、 米国で 30 年間も研究を続けており、 同社の他の役員も米国の大手バイオテ ク会社での勤務経験がある。これまで のところ、メディシノバ社は、喘息か らがんに至るさまざまな病気の治療を 目的とする 6 種類の薬物候補の臨床試 験をすすめている。

メディシノバ社の株式を日本で上 場させたのは、薬物候補を提供する パートナー企業との関係強化に役立 つ側面があるためだ、と岩城は語る。 しかし上場当初からメディシノバ社 は、個人投資家のような投機的売買を しない、安定した大口取引をしてくれ る機関投資家に株式を購入させるた めに苦労した。最近まで日本の投資家 が日本国内で上場された外資系企業 の株式の売買をするには、東京証券 取引所の子会社である日本証券決済 株式会社を通す必要があった。しかし 銀行や証券会社などの機関投資家は、 このルートを使うことが許されていな かった。その代わり、機関投資家が例 えば東京にも上場しているボーイン グ社の株式を買いたいと思えば、海外 に出て、ニューヨーク証券取引所で買 わなければならなかった。
メディシノバ社は、中国の新華ファ イナンス社と並んで、日本に単独上 場する唯一の外資系企業である。そ れゆえ、制度の不備によって両社は 苦境に追い込まれた。この問題は、5 月になって日本の金融庁が証券保管 振替機構に対して機関投資家との外 資系企業株式取引決済を許可したこ とで解決した、と岩城はいう。

一方、個人投資家は、別の問題に 直面していた。メディシノバ社の株 価が、なかなか一般紙に掲載されな かったのだ。また、同社の四半期報 告書やその他の企業情報も、日本の 個人投資家に人気のあるヤフーなど のウェブサイトに掲載されなかった。 それは、インターネット企業が情報 を日本のウェブサイトで現在使用さ れている円表示に直ちに換算できな かったことによる。(メディシノバ社 は米国規則を遵守するため、米ドル 表示による決算報告をしている。）こ

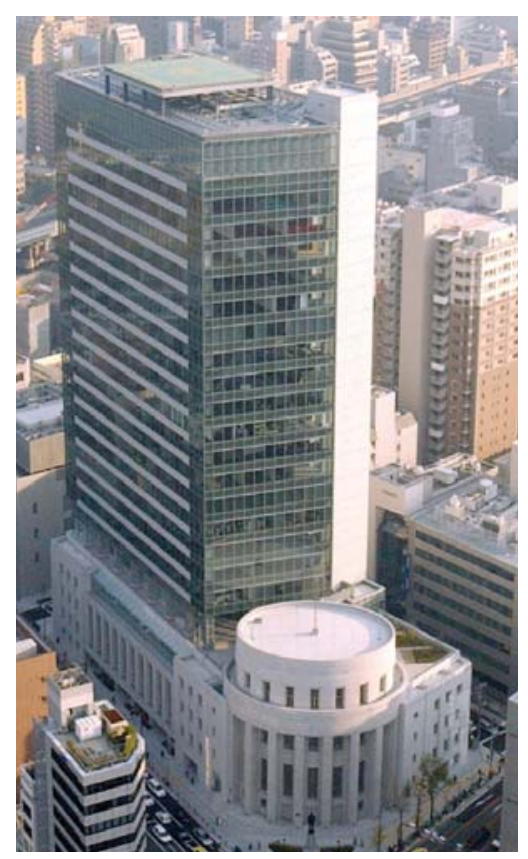

大阪証券取引所

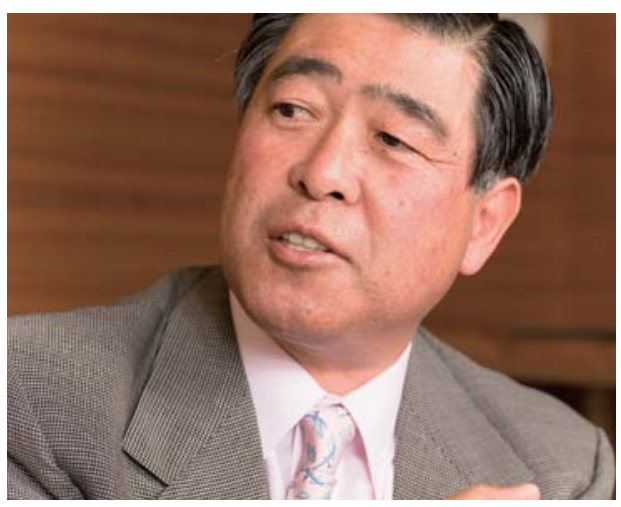

岩城裕一の会社は、大阪証券取引所に上場以来、厳しい 状態が続いている。

れらの問題のため、個人投資家はメ ディシノバ社の株式に警戒感をもっ てしまった、と岩城は主張する。

株主とのコミュニケーションを高め るため、最近、メディシノバ社は、日 本語ウェブサイトを一新させ、岩城も 自分自身のブログを日本語で掲載し、 企業イメージの改善をねらっている。

メディシノバ社が困難な目にあった のは、日本の株式市場での上場に固有 の問題のためではなく、上場のための 準備が不足していたからだとする専門 家もいる。「メディシノバ社はスピード を重視しすぎたと思います。日本では 一歩一歩順を追って実行していくのが 大切なのです。こう語るのは、2007 年末に東京証券取引所での上場を計画 している Cangen Biotechnologies 社（米国メリーランド州ベセズダ）の 最高経営責任者の Chul So Moon だ。

日本での上場を考える他の外資系 バイオテク企業は、メディシノバ社 の経験を教訓にできる、と縣は考え ている。「メディシノバ社のおかげで、 日本の制度の問題点が表面化ました。 今後この業界がどのように対応する のか、長い目で見ていく必要があり ます」と彼は話す。 